\title{
ESTIMATION OF RAINFALL BASED ON REMOTE SENSING AND OBSERVATION FIELDS IN JARU BIOLOGICAL RESERVE AT THE BRAZILIAN AMAZONIAN FOREST
}

\author{
Keylyane Santos da Silva Alves \\ Federal University of Mato Grosso, Department of Physics, Av. Fernando Correa da Costa, 2367, Cuiabá, MT, 78.060- \\ 900, Brazil \\ Corresponding author: keylyanesds@gmail.com
}

\section{Luciana Sanches}

Federal University of Mato Grosso, Department of Sanitary and Environmental Engineering, Av. Fernando Correa da Costa, 2367, Cuiabá, MT, 78.060-900, Brazil

Nara Luísa Reis de Andrade

Federal University of Rodônia, Departamento of Enviromental Engeneering, Rio Amazonas, 351 B, Jardim dos Migrantes, Ji-Paraná, RO, 76900-726, Brazil

\section{Gracyeli Santos Souza Guariente}

Federal University of Mato Grosso, Department of Computer Engineering, Av. Fernando Correa da Costa, 2367, Cuiabá, MT, 78.060-900, Brazil

\section{Peter Zeilhofer}

Federal University of Mato Grosso, Department of Geography, Av. Fernando Correa da Costa, 2367, Cuiabá, MT, 78.060-900, Brazil

\begin{abstract}
The Amazon basin, with a drainage area of about 6 million $\mathrm{km}^{2}$, is the largest drainage basin in the world, consequently the accurate measuring the rainfall dynamics at high spatial and temporal resolution is essential for a better understanding of the hydrological cycle. So, we validated rainfall estimates from the Tropical Rainfall Measuring Mission (TRMM) satellite using surface precipitation data collected from 2004 to 2012. Rainfall data came from the Jaru Biological Reserve meteorological station, located to the east in the state of Rondônia, Brazil, and was compared with the estimates of the algorithms 3B42 V7 and 3B43 V7 of the product TRMM. Statistical analysis was based on indices of continuous variables such as the Spearman correlation coefficient $(\rho)$, the square root mean square error normalized by the mean of the observed values (NRMSE), the mean square error (RMSE), the error (ERV) and some categorical indices such as probability of detection (POD), False Alarm (FAR) and critical success rate (CSI) between the daily and monthly precipitation observed data and the estimated precipitation data. The 3B43 V7 precipitation estimates were broadly representative of surface observations, but underestimated precipitation in the wet season and overestimated precipitation in the dry season. The 3B42 V7 product performed poorly and does not generate a robust representation of surface precipitation.
\end{abstract}

Index terms: Precipitation assessment, tropical precipitation, product TRMM.

Received: October, 10, 2020 - Accepted: April, 16, 2021

\section{INTRODUCTION}

The Amazon basin, with a drainage area of about 6 million $\mathrm{km}^{2}$, is the largest drainage basin in the world and contains the Amazon River which accounts for about $15 \%$ of the total volume of fresh water reaching the global oceans (Correa et al., 2017; Hoorna et al., 2017). As a consequence of its size, the Amazon basin is crucial for atmospheric circulation: the dominant moisture flow in the basin derives from oceanic water vapor, however, airflow is blocked by the Andes and evaporated moisture is therefore transported to the South (Van Der Ent et al., 2010; Arraut et al., 2012). Consequently, any atmospheric disruptions in the basin could have significant consequences for the hydrological cycle of the entire South American continent, 
possibly extending to other parts of the world (Correia et al., 2007).

The precipitation regime in the Amazon region is modulated at multiple scales: i) dynamic microscale systems are driven by local convections derived from daytime surface heating; ii) mesoscale dynamics are influenced by, for example, conglomerates of cumulonimbus clouds associated with the lines of instabilities caused by the sea breeze circulation on the Atlantic coast, and; iii) macroscale systems include the thermal circulations and the convective agglomerates that form the South Atlantic convergence zone. Such dynamics and interactions of these systems generate intense spatial and temporal variability in the climate and precipitation patterns of the Amazon region (Correia et al., 2007).

Accurately measuring the rainfall dynamics at high spatial and temporal resolution is essential for a better understanding of the hydrological cycle of the Amazon river basin (Immerzeel et al., 2009). Such knowledge is important because precipitation drives most hydrological and environmental processes and therefore impacts on the global energy and water economy (Hunink et al., 2014; Wanders and Pan, 2015). However, high resolution monitoring of precipitation is not straightforward. The conventional approach is to use rain gauges, though there are practical limits on how many of these can be deployed and on their spatial distribution. For these reasons, precipitation patterns and maps are based on models and the recorded data is only used for validation (Tapiador et al., 2017). Validation data is typically from sites that are representative of their area (Kidd et al., 2017), notwithstanding that these measures are also subject to errors of recovery and bias (Tapiador et al., 2017).

In regions such as the Amazon basin, rainfall density is typically very low and rainfall is highly variable due to convective precipitation. For these reasons accurate estimations of rainfall derived from remote sensing data can be very useful (Collischonn et al., 2008). For the purposes of validations, remote sensing products (whether from terrestrial radar or spatial sensors) can generate estimates for the specific time and place of verification (Trenberth et al., 2017). This is necessary because although satellite data products have much better coverage than the data used for calibration, they have their own uncertainties (Tapiador et al., 2017). A global map of uncertainties of current satellite precipitation products suggested that estimates were more reliable in areas with strong convective precipitations and flat surfaces (Tian and Peters-Lidard, 2010).

The Tropical Rainfall Measuring Mission (TRMM) products are one for the main tools for estimating precipitation in the Amazon and are being continually improved as an increasing amount of high- and medium-resolution remote sensing data on biophysical surface properties is becoming available. Indeed, the Amazon region appears to have a high concordance between satellite estimates of precipitation and calibration data from rainfall gauges, even for more variable daily data (Collischonn et al., 2008), but this variable can be dependent on microlocal. In the present study, our objective was to compare the precipitation estimates of two products (algorithms) of the Tropical Rainfall Measuring Mission (TRMM), 3B42V7 and 3B43V7, with data derived from rainfall gauge measurements. By doing so we aim to evaluate the performance of these TRMM products in the Southwest Amazon during 2004 to 2012.

\section{MATERIAL AND METHODS}

\section{Study Area}

The Jaru Biological Reserve (REBIO Jaru) is a strict protected area under federal jurisdiction, located east of the state of Rondônia, approximately $80 \mathrm{~km}$ from the city of Ji-Paraná Brazil, between latitudes $09^{\circ} 19^{\prime} 52^{\prime \prime}$ and $10^{\circ} 11^{\prime} 46^{\prime \prime}$ $S$ and longitudes $61^{\prime \prime} 35^{\prime} 40^{\prime \prime}$ and $61^{\circ} 52^{\prime} 48^{\prime \prime} \mathrm{W}$ and has an area of approximately $353,166,0$ hectares (Figure 1).

The vegetation is open ombrophiles forest (Culf et al., 1996; Rottenberger et al., 2004), commonly referred to as seasonally dry or semideciduous tropical forest (Rottenberger et al., 2004; Costa et al., 2010). The vegetation cover has an average canopy height of approximately 35 meters. 


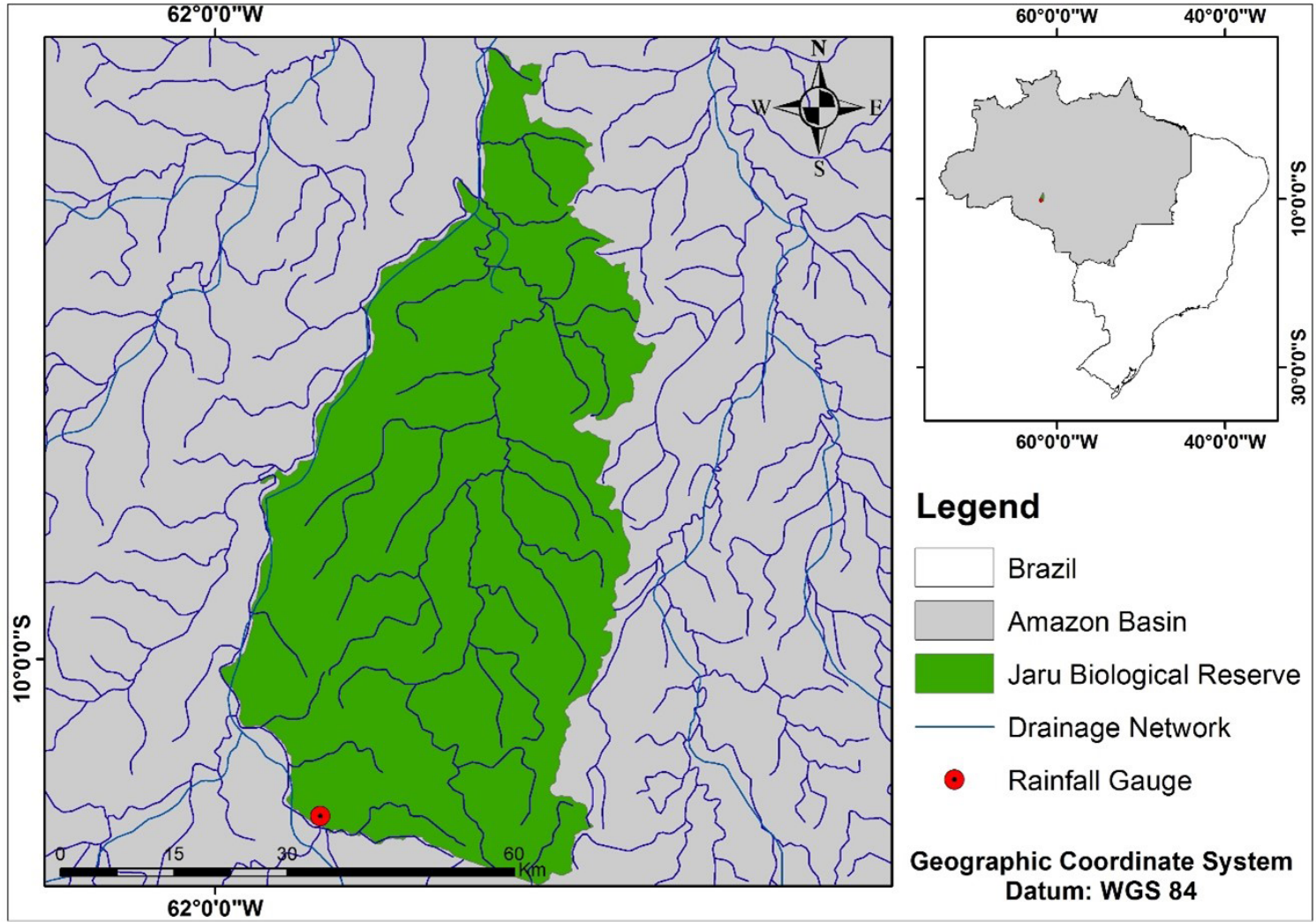

Figure 1: Localization of the Jaru Biological Reserve and the meteorological station in the state of Rondônia, Brazil.

The reserve has a mean elevation of 485 meters with a marked relief gradient. The soil of the reserve is classified as red-yellow podzolic (Hodnett et al., 1996).

According to Köppen, the regional climate region is type Aw - Tropical Climate humid and dry - with average climatological air temperature of above $18{ }^{\circ} \mathrm{C}$ during the coldest month and a well-defined dry period during the dry season, when a moderate water deficit occurs with rainfall of less than $50 \mathrm{~mm} /$ month (França, 2015). According to on-site measurements, the mean annual temperature is $25^{\circ} \mathrm{C}$, the mean relative humidity is $82 \%$ and the average annual precipitation index is over $2000 \mathrm{~mm}$.

\section{Rainfall gauge}

Rainfall data measured at the REBIO Jaru meteorological station, located at coordinates $10^{\circ} 11^{\prime} 11.4^{\prime \prime S}$ and $61^{\circ} 52^{\prime} 29.9^{\prime \prime} \mathrm{W}$, were provided by the tower network of the Large-Scale Biosphere- Atmosphere in the Amazon (LBA Program) between January 2004 and December 2012.
The rainfall was measured using a pluviometer (ARG-100, Campbell Scientific, Barcelona, Spain) connected to a data acquisition system (Datalogger CR10X, Campbell Scientific Instrument, Utah, USA) programmed to read the measurements every $30 \mathrm{~s}$ and then store an average every 10, 30 and $50 \mathrm{~min}$. The rain gauge was installed at $62 \mathrm{~m}$ above ground level.

\section{TRMM products}

Rainfall data estimated by the TRMM satellite were made available free of charge from NASA's website (<www.nasa.gov/, last access: 18 august 2016). We used data from two products: 3B42 V7 TRMM "Daily" and the 3B43 V7 TRMM "Monthly". The first product can be used to estimate daily cumulative precipitation, derived from the product 3B42V7 RT-3"Hourly" (HUFFMAN et al., 1995). TRMM 3B42V7 provides an estimative of precipitation in a latitude band covering $50^{\circ} \mathrm{N}$ at $50^{\circ} \mathrm{S}$, of all global data sources, namely high-quality microwave data, infrared data and analysis of rain indicators. 
Satellite precipitation estimates were obtained from the TRMM - Multisatellite Precipitation Analysis (TMPA). This technique consists of a combination of precipitation estimates of the microwave channel "TRMM Microwave Imager" (TMI available: http:// trmm.gsfc.nasa.gov/3b42.html and http:// trmm.gsfc.nasa.gov/3b43.html. Last access: august 2016), "Special Sensor Microwave Imager" (SSM/I), "Advanced Microwave Scanning Radiometer" (AMSR-E), "Advanced Microwave Sounding Radiometer" (AMSU-B), infrared (IR) channel through the "Goes Precipitation Index" (GPI) and with monthly rainfall information from "Global Precipitation Climatology Centre" (GPCC) (Huffman et al., 2007).

The product has a spatial resolution $0.25^{\circ} \times 0.25^{\circ}$ for latitudes $50^{\circ} \mathrm{N}$ and $50^{\circ} \mathrm{S}$ and longitude $180^{\circ} \mathrm{W}$ and $180^{\circ} \mathrm{E}$, with data from 1998 to the present and were released in 2012. According to the algorithm developer, several important changes are present in TMPA version 7 products (Huffman et al., 2015).

\section{Validation of TRMM products}

We statistically evaluated the quality of the estimates obtained for the pixel that overlaps the rainfall gauge to verify if the TRMM products accurately estimate the recorded precipitation regime. Specifically, we used a Shapiro-Wilk normality test to identify if the data was normally distributed $(p=0.001)$. We also used the Spearman correlation coefficient $(\rho)$, the square root of the mean square error normalized by the mean of the observed values or NRMSE, the RMSE, and the relative error (Errv (\%) to compare the results.

Additionally, a quantitative verification of the daily multisatellite product for the detection of rainy-day events was performed using probability of detection (POD), false alarm rate (FAR) and critical success rate (CSI) (based on Wilks, 2006).

$$
P O D=\frac{H}{H+F}
$$

$F A R=\frac{F}{H+F}$

$C S I=\frac{H}{H+M+F}$

where; $\mathrm{H}$ is the precipitation measured by gauge and predicted by the TRMM satellite; $\mathrm{M}$ is the precipitation measured and but not predicted by the TRMM satellite; $F$ is the precipitation predicted by the TRMM satellite, but not measured by gauge.

\section{RESULTS AND DISCUSSION}

The TRMM 3B43 V7 product generated minimum indices from May to September and maximum indices during October to April (Figure 2). As larger amplitudes between the maximum and minimum indices occurred in the rainy season.

In relation to the rainfall gauge data, the TRMM product estimates were better for annual than monthly and daily periods (Figure 3 ).

For all seasons and annually, the TRMM 3B43 V7 data was more strongly correlated with the recorded data than TRMM 3B42 V7 data (Table $1)$; for precipitation with an intensity greater than $25 \mathrm{~mm} /$ day the results of TRMM 3B42 V7 became less satisfactory, supporting the findings of Almazroui (2011) for precipitation characteristics in Saudi Arabia from 1999 to 2009 and of Islam and Uyeda (2007), who calibrated TRMM precipitation estimates in Bangladesh from 1998 to 2002 (Table 2).

The strongest correlations between estimated and recorded precipitation occurred in the rainy season. However, TRMM 3B43V7 tended to overestimate rainfall in the dry season and underestimate precipitation in the wet season. Condom et al. (2011) observed the same pattern in TRMM 3B43V7 in a mountainous area of Peru during 1998-2007, and were able to improve their results significantly by adjusting the algorithm.

Our results contrast with those of Duan and Bastiaanssen (2013) for Ethiopia and Iran, where the strongest correlations occurred in the dry 
season and the weakest correlations were found in the rainy season (Table 2). This can probably be explained by the precipitation pattern in the study area being different from the Amazonian basin. However, Zheng and Zhu (2014) (using the 3B43 V7 TRMM product) observed a similar pattern in a similarly forested region of northern China.

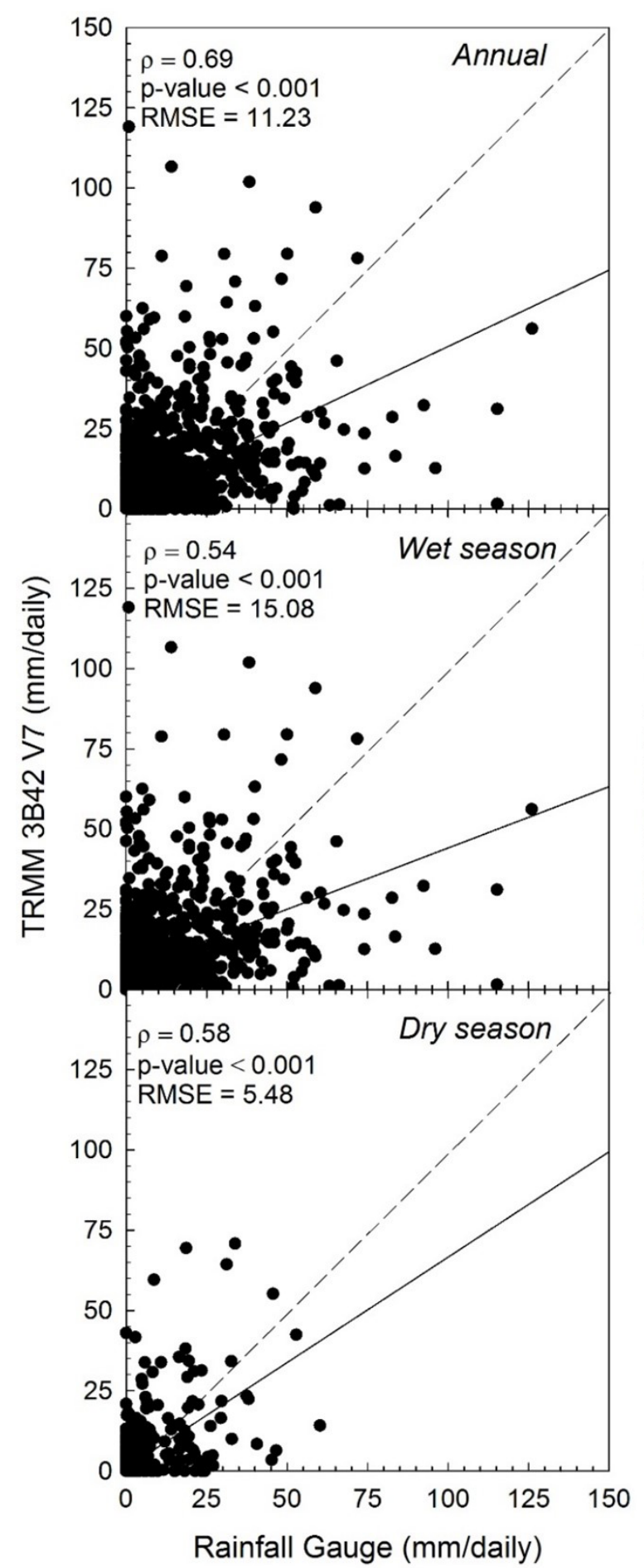

Mean NRMSE was $51.31 \%$ (at least 5 times lower than the NRMSE found for TRMM 3B42) (Table 1) - within the limit for the safe use of these data (Adeyewa and Nakamura, 2003).

In the dry season, the magnitude of the product error in the precipitation estimation was high (NRMSE> 90\%), whereas the

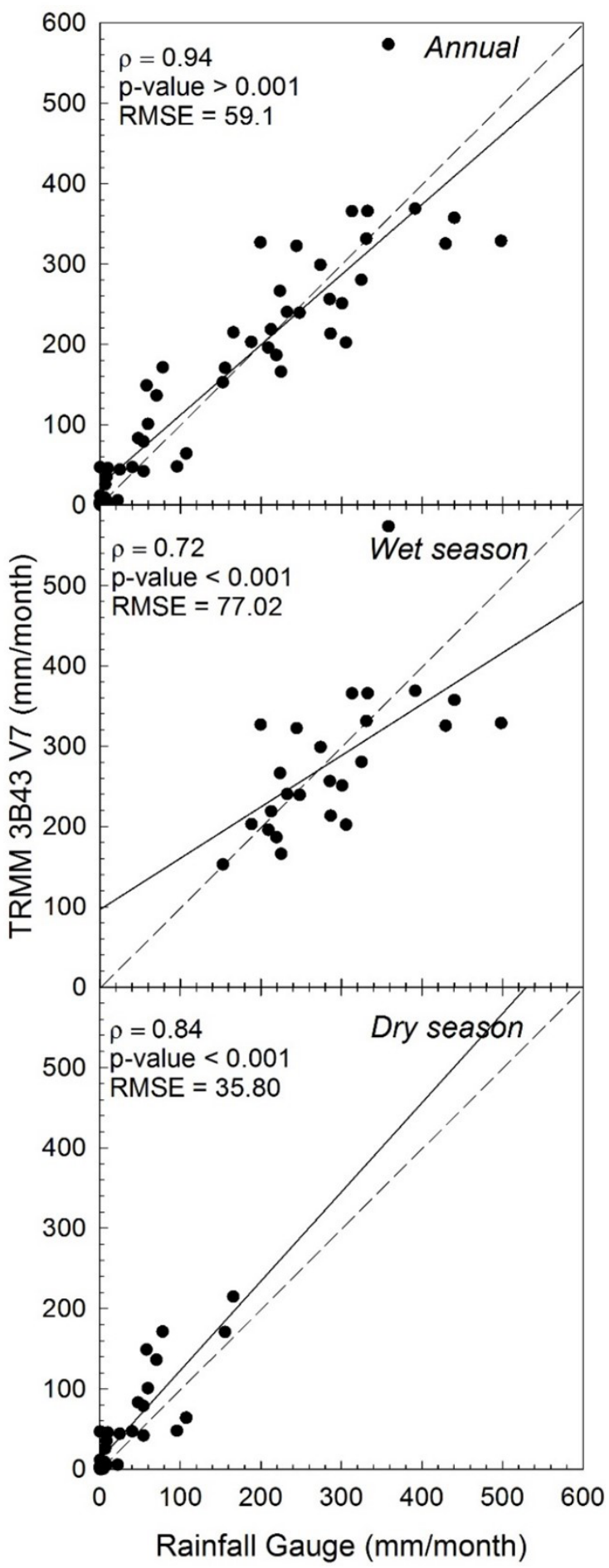

Figure 2: Relationship between rainfall gauge (mm/daily) and 3B42 V7 TRMM (mm/day) during annual, wet and dry period. Solid line represents the slope of the line and dashed line 1:1. 
difference in 3B43V7 TRMM in relation to the rain gauge was the lowest (RMSE $<40$ $\mathrm{mm})$. In this case, the RMSE during the dry season approached the average precipitation, reaching a NRMSE value close to $100 \%$ (the average dry season was 4.13 times the interannual average of the precipitation). These results corroborate studies in Peru (Condom et al., 2011), Iran and the south east of the Caspian Sea (Darand et al., 2017) (Table 2).

The fact that TRMM products are more accurate for annual data agrees with Nastos et al. (2016), who analysed the performance of TRMM 3B43V7 for the Integrated Greek Domain. They also observed a stronger correlation for the annual period (Table 2). These results also agree with Collischonn et al. (2008) who analyzed TRMM 3B42V7 for the Tapajós basin in the Amazon forest, Brazil, and Soares et al. (2016) for the coastal region of the state of Paraíba, Brazil (Table 2).

With respect to POD values, TRMM 3B43 V7 better able to detect precipitation measured by caliber than the 3B42 V7 TRMM product. The TRMM 3B43 V7 had a POD equal to 1 , indicating that the total number of precipitation occurrences was accurately detected by the TRMM product with no false detections confirmed by the FAR index of 0.06 to 0.1 . The wet season produced the best index values (Table 1).

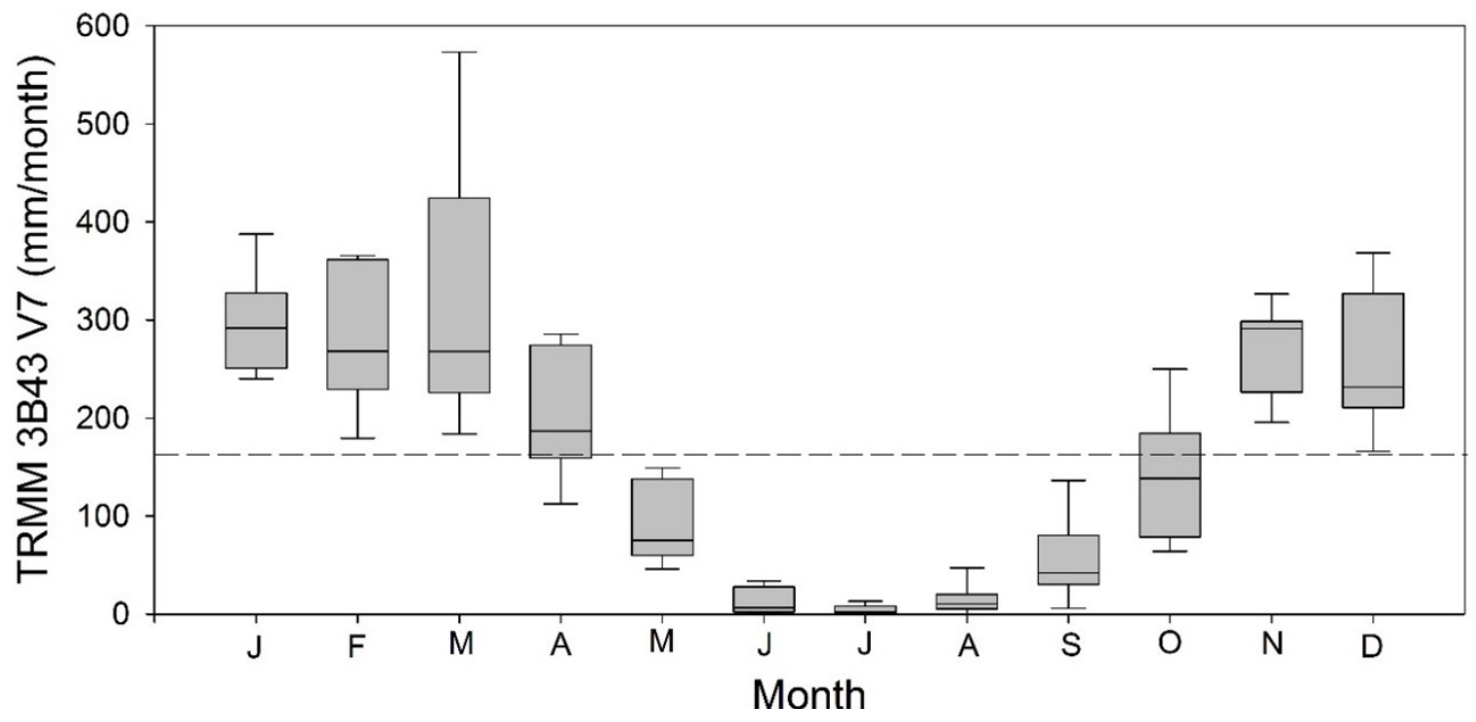

Figure 3: Boxplot for 3B43 V7 TRMM from 2004 to 2012. Each box lies between the 0.25 and the 0.75 quartile, and the central line is the median. The whiskers indicate the range of the data within the maximum and the minimum values.

Table 1: Spearman Correlation coefficient $(\rho)$, Square Root Mean Square Error (RMSE), Square Root Mean Square Error Normalized by Average Observed Values (NRMSE), Relative Error (Errv), Probability of Detection (POD), False Alarm Ratio (FAR) and Critical Success Index (CSI) in Pixel Validation of 3B42 and 3B43 V7 TRMM Products. The asterisk indicates the level of significance of the coefficients: $\mathrm{p}$-value $\left(^{*}\right)$ p-value $\leq 0.001$.

\begin{tabular}{ccccccccc}
\hline Product & Period & $\boldsymbol{\rho}$ & RMSE & NRMSE (\%) & Errv (\%) & POD & FAR & CSI \\
\hline \multirow{3}{*}{ TRMM 3B42 } & Annual & $0.69^{*}$ & 11.23 & 223.35 & 9.2 & 0.8 & 0.23 & 0.66 \\
& Wet & $0.54^{*}$ & 15.08 & 171.67 & 5.56 & 0.9 & 0.17 & 0.74 \\
& Dry & $0.58^{*}$ & 5.48 & 374.74 & 30.02 & 0.65 & 0.35 & 0.48 \\
\hline \multirow{3}{*}{ TRMM 3B43 } & Annual & $0.91^{*}$ & 59.1 & 37.80 & 3.13 & 1 & 0.06 & 0.92 \\
& Wet & $0.72^{*}$ & 77.02 & 26.65 & -2.63 & 1 & 0.06 & 1 \\
& Dry & $0.84^{*}$ & 35.80 & 95.48 & 43.03 & 0.96 & 0.11 & 0.86 \\
\hline
\end{tabular}


Kim et al. (2017) observed that TRMM 3B42 (Table 2) does not accurately detect rainfall occurring during monsoon periods when compared to estimates of rainfall in dense forests and mountain regions over central Korea, South Korea, and Japan. The TRMM satellite is imprecise when detecting low altitude convective precipitation, which may have occurred during daily precipitation estimates by the 3B42 TRMM product. The limitations of the satellite algorithm data may be due to other reasons. Fu and Liu (2007) explain that the satellite has only a dispersion index to capture shallow rains, which is insufficient for calibration. Furthermore, Qi et al. (2013) state that the TRMM 3B42 product may incorrectly classify convective precipitation because the radar brightness reflectivity band contains an error caused by its limited vertical resolution.

The relative error measure indicated that the TRMM 3B42 V7 overestimated the precipitation by $14.92 \%$ on average (Table 1 ). However, in the dry season, overestimation was more evident (Errv $=30 \%)$. These results corroborate with Collischonn et al. (2007), who found an $8 \%$ positive bias in the Paraguay basin in the state of Mato Grosso, Brazil, with Koo et al. (2009) in South Korea who observed a bias of $38.39 \%$ and Guo and Liu (2016) who recorded a bias of $3.55 \%$ for Poyang Lake Region in China (Table 2).

The TRMM 3B43 product tends to overestimate rainfall by $14.51 \%$ on average over the three study periods. In the rainy season (November to April), the relative error was $-2.63 \%$, indicating an underestimation of precipitation. In the dry season (May to October), the relative error was positive, indicating that during this season the precipitation estimated by the TRMM 3B43 V7 is higher than the rain gauge (Table 1). These results agree with Guo and Liu (2016) who evaluated the estimated rainfall of TRMM products based on Lake Poyang (China) from 1998 to 2007 (Table 2). These authors mention that TRMM 3B43V7 tends to overestimate monthly precipitation when the rate is $<200$ $\mathrm{mm} / \mathrm{month}$ and underestimate precipitation when the rate is $<400 \mathrm{~mm} /$ month.

Collischonn et al. (2008) reported a relative error of $-10 \%$ to $+10 \%$ for comparison between TRMM products and rain gauges over the Tapajós river basin. Condom et al. (2011), analyzing the quality of TRMM 3B43 V7 in Peru, confirmed that in the rainy season negative differences occur between the precipitation estimated by the TRMM $3 \mathrm{~B} 43 \mathrm{~V} 7$ and the rain gauges. This indicates an underestimate of precipitation by the product, and inversely, a positive value for the difference between the TRMM 3B43 V7 and the data observed by the rain gauges in the dry period (Table 2).

The superior accuracy of the TRMM 3B43 V7 compared to TRMM 3B42 V7 is mainly due to errors in the daily scale being almost symmetrical and therefore canceling each other out after aggregation (Darand et al., 2017). The weak correlations between the TRMM 3B42 V7 product estimates and the data from the rainfall gauge is probably due to its use of corrections based on surface precipitation meters. However, adjustments are made only with meters that provide data in real time, which does not occur with the meteorological station (Collischonn et al., 2008). There is general agreement between the rainfall gauge and TRMM 3B43 V7. This is due to the product algorithm that was elaborated based on data corrections of surface rain gauges that emit data of accumulated monthly precipitation (Huffman et al., 2010). A better concordance was obtained during low rainfall periods, in contrast to some underestimation during periods of higher precipitation. These mismatches can be largely explained by the resolution of the pixel grid of products derived from the TRMM satellite (approximately 25 $\mathrm{km})$ compared to surface meters representing only a few meters of area of influence of precipitation records (Almazroui, 2011).

Islam et al. (2015) suggest that the TRMM satellite struggles to detect convective precipitation when it develops at low altitudes, which may have occurred with 
the daily precipitation estimated by 3B42 V7 TRMM product. Moreover, the satellite has only a scatter index for shallow rains, which is insufficient for calibration (Fu and $\mathrm{Liu}$, 2007). As mentioned above, Qi et al. (2013) suggest that the TRMM $3 \mathrm{~B} 42 \mathrm{~V} 7$ product may misclassify convective precipitation because the radar brightness reflexivity band contains an error caused by its limited vertical resolution.

Table 2: Comparison of the results found for the products TRMM 3B42 and TRMM 3B43 in this study with another research.

\begin{tabular}{|c|c|c|c|c|c|c|}
\hline Product & Results & Period & Other studies & Authors & Region & $\begin{array}{c}\text { Description } \\
\text { of Places }\end{array}$ \\
\hline \multirow{17}{*}{$\begin{array}{l}\text { TRMM } \\
\text { 3B42 }\end{array}$} & $\begin{array}{l}\text { Correlation } \\
\text { coefficient }\end{array}$ & $\begin{array}{l}\text { Wet } \\
\text { Dry }\end{array}$ & $\begin{array}{l}0.5-0.8 \\
\quad>0.5\end{array}$ & Soares et al. (2016) & Paraíba & $\begin{array}{c}\text { Paraiba Forest, } \\
\text { Agreste, Borborema } \\
\text { and Sertão }\end{array}$ \\
\hline & $\begin{array}{l}\text { Correlation } \\
\text { coefficient }\end{array}$ & Total & $0.25-0.64$ & Collischonn et al. (2007) & $\begin{array}{c}\text { Upper Paraguay } \\
\text { Basin }\end{array}$ & $\begin{array}{c}\text { Pantanal } \\
\text { Matogrossense }\end{array}$ \\
\hline & Errv (\%) & Total & $8 \%$ & Collischonn et al. (2007) & $\begin{array}{c}\text { Upper Paraguay } \\
\text { Basin }\end{array}$ & $\begin{array}{c}\text { Pantanal } \\
\text { Matogrossense }\end{array}$ \\
\hline & $\begin{array}{l}\text { Correlation } \\
\text { coefficient }\end{array}$ & Total & $0.14-0.62$ & Collischonn et al. (2008) & Tapajós River Basin & $\begin{array}{l}\text { Amazon basin } \\
\text { (forest) }\end{array}$ \\
\hline & Errv (\%) & Total & $-12 a+12 \%$ & Collischonn et al. (2008) & Tapajós River Basin & $\begin{array}{l}\text { Amazon basin } \\
\text { (forest) }\end{array}$ \\
\hline & $\begin{array}{l}\text { POD } \\
\text { FAR } \\
\text { CSI }\end{array}$ & $\begin{array}{l}\text { Annual } \\
\text { Average }\end{array}$ & $\begin{array}{l}0.58 \\
0.37 \\
0.43 \\
\end{array}$ & Kim et al. (2017) & Central Korea & $\begin{array}{c}\text { Dense forests } \\
\text { and mountainous } \\
\text { regions }\end{array}$ \\
\hline & $\begin{array}{l}\text { POD } \\
\text { FAR } \\
\text { CSI }\end{array}$ & $\begin{array}{l}\text { Annual } \\
\text { Average }\end{array}$ & $\begin{array}{l}0.64 \\
0.23 \\
0.53\end{array}$ & Kim et al. (2017) & South Korea & $\begin{array}{c}\text { Dense forests } \\
\text { and mountainous } \\
\text { regions }\end{array}$ \\
\hline & $\begin{array}{l}\text { POD } \\
\text { FAR } \\
\text { CSI }\end{array}$ & $\begin{array}{l}\text { Annual } \\
\text { Average }\end{array}$ & $\begin{array}{l}0.62 \\
0.29 \\
0.49\end{array}$ & Kim et al. (2017) & Japan & $\begin{array}{c}\text { Dense forests } \\
\text { and mountainous } \\
\text { regions }\end{array}$ \\
\hline & BIAS & $\begin{array}{l}\text { Pre-monsoon } \\
\text { Monsoon }\end{array}$ & $\begin{array}{c}+20.73 \% \\
-11.3 \% \\
\end{array}$ & Islam and Uyeda (2007) & Bangladesh & All Bangladesh \\
\hline & BIAS & Wet & $38.38 \mathrm{~mm}$ & Koo et al. (2009) & South Korea & Temperate Climate \\
\hline & RMSE & Wet & $84.39 \mathrm{~mm}$ & Koo et al. (2009) & South Korea & Temperate Climate \\
\hline & $\begin{array}{l}\text { Correlation } \\
\text { coefficient }\end{array}$ & Wet & 0.91 & Koo et al. (2009) & South Korea & Temperate Climate \\
\hline & $\begin{array}{l}\text { Correlation } \\
\text { coefficient }\end{array}$ & Daily & 0.17 & Guo and Liu (2016) & $\begin{array}{l}\text { Lake Poyang } \\
\text { in China }\end{array}$ & Mountainous region \\
\hline & RMSE & Daily & $18.10 \mathrm{~mm}$ & Guo and Liu (2016) & $\begin{array}{l}\text { Lake Poyang } \\
\text { in China }\end{array}$ & Mountainous region \\
\hline & NRMSE & Daily & $200.04 \%$ & Guo and Liu (2016) & $\begin{array}{c}\text { Lake Poyang } \\
\text { in China }\end{array}$ & Mountainous region \\
\hline & BIAS & Daily & $3.55 \%$ & Guo and Liu (2016) & $\begin{array}{l}\text { Lake Poyang } \\
\text { in China }\end{array}$ & Mountainous region \\
\hline & $\mathrm{ME}$ & Daily & $0.32 \mathrm{~mm}$ & Guo and Liu (2016) & $\begin{array}{l}\text { Lake Poyang } \\
\text { in China }\end{array}$ & Mountainous region \\
\hline
\end{tabular}


Table 2: Continuation.

\begin{tabular}{|c|c|c|c|c|c|c|}
\hline & $\begin{array}{l}\text { Correlation } \\
\text { coefficient }\end{array}$ & Annual & 0.96 & Nastos et al. (2016) & Greece & All Greek complex \\
\hline & RMSE (mm) & Annual & 79.2 & Nastos et al. (2016) & Greece & All Greek complex \\
\hline & CSI & Monthly & $0.4-0.9$ & Nastos et al. (2016) & Greece & All Greek complex \\
\hline & $\begin{array}{l}\text { Correlation } \\
\text { coefficient }\end{array}$ & $\begin{array}{l}\text { Wet } \\
\text { Dry }\end{array}$ & $\begin{array}{l}\text { Negative } \\
\text { Positive }\end{array}$ & Condom et al. (2011) & Peru & Mountainous region \\
\hline & RMSE & Monthly & $>50 \%$ & Condom et al. (2011) & Peru & Mountainous region \\
\hline & RMSE & Monthly & $0-163 \mathrm{~mm}$ & Darand et al. (2017) & $\begin{array}{c}\text { Iran and } \\
\text { southeastern parts } \\
\text { of the Caspian Sea }\end{array}$ & $\begin{array}{c}\text { Coastal and } \\
\text { Mountainous Areas }\end{array}$ \\
\hline & $\begin{array}{l}\text { Correlation } \\
\text { coefficient }\end{array}$ & Monthly & 0.98 & Darand et al. (2017) & $\begin{array}{c}\text { Iran and } \\
\text { southeastern parts } \\
\text { of the Caspian Sea }\end{array}$ & $\begin{array}{c}\text { Coastal and } \\
\text { Mountainous Areas }\end{array}$ \\
\hline & RRMSE & $\begin{array}{l}\text { Wet } \\
\text { Dry }\end{array}$ & $\begin{array}{l}92.43 \% \\
60.89 \% \\
\end{array}$ & Zheng and Zhu (2014) & Northern China & Forest Regions \\
\hline & $\begin{array}{c}\text { Correlation } \\
\text { coefficient }\end{array}$ & $\begin{array}{l}\text { Wet } \\
\text { Dry }\end{array}$ & $\begin{array}{l}0.46 \\
0.39\end{array}$ & Zheng and Zhu (2014) & Northern China & Forest Regions \\
\hline & $\begin{array}{l}\text { Correlation } \\
\text { coefficient }\end{array}$ & $\begin{array}{l}\text { Wet } \\
\text { Dry }\end{array}$ & $\begin{array}{l}0.49 \\
0.60 \\
\end{array}$ & $\begin{array}{c}\text { Duan and } \\
\text { Bastiaanssen (2013) }\end{array}$ & $\begin{array}{l}\text { Lake Tana Basin } \\
\text { in Ethiopia }\end{array}$ & Arid Climate \\
\hline & $\begin{array}{l}\text { Correlation } \\
\text { coefficient }\end{array}$ & $\begin{array}{l}\text { Wet } \\
\text { Dry }\end{array}$ & $\begin{array}{l}0.87 \\
0.82\end{array}$ & $\begin{array}{c}\text { Duan and } \\
\text { Bastiaanssen (2013) }\end{array}$ & $\begin{array}{l}\text { Iran Caspian } \\
\text { Sea Region }\end{array}$ & Arid Climate \\
\hline TRMM & RMSE & $\begin{array}{l}\text { Wet } \\
\text { Dry }\end{array}$ & $\begin{array}{l}434 \mathrm{~mm} \\
294 \mathrm{~mm}\end{array}$ & $\begin{array}{c}\text { Duan and } \\
\text { Bastiaanssen (2013) }\end{array}$ & $\begin{array}{l}\text { Lake Tana Basin } \\
\text { in Ethiopia }\end{array}$ & Arid Climate \\
\hline & RMSE & $\begin{array}{l}\text { Wet } \\
\text { Dry }\end{array}$ & $\begin{array}{l}219 \mathrm{~mm} \\
179 \mathrm{~mm}\end{array}$ & $\begin{array}{c}\text { Duan and } \\
\text { Bastiaanssen (2013) }\end{array}$ & $\begin{array}{l}\text { Iran Caspian } \\
\text { Sea Region }\end{array}$ & Arid Climate \\
\hline & MAE & $\begin{array}{l}\text { Wet } \\
\text { Dry }\end{array}$ & $\begin{array}{l}344 \mathrm{~mm} \\
239 \mathrm{~mm}\end{array}$ & $\begin{array}{c}\text { Duan and } \\
\text { Bastiaanssen (2013) }\end{array}$ & $\begin{array}{l}\text { Lake Tana Basin } \\
\text { in Ethiopia }\end{array}$ & Arid Climate \\
\hline & MAE & $\begin{array}{l}\text { Wet } \\
\text { Dry }\end{array}$ & $\begin{array}{l}178 \mathrm{~mm} \\
140 \mathrm{~mm}\end{array}$ & $\begin{array}{c}\text { Duan and } \\
\text { Bastiaanssen (2013) }\end{array}$ & $\begin{array}{l}\text { Iran Caspian } \\
\text { Sea Region }\end{array}$ & Arid Climate \\
\hline & BIAS & $\begin{array}{l}\text { Wet } \\
\text { Dry }\end{array}$ & $\begin{array}{c}0.00 \\
-0.04 \\
\end{array}$ & $\begin{array}{c}\text { Duan and } \\
\text { Bastiaanssen (2013) }\end{array}$ & $\begin{array}{l}\text { Lake Tana Basin } \\
\text { in Ethiopia }\end{array}$ & Arid Climate \\
\hline & BIAS & $\begin{array}{l}\text { Wet } \\
\text { Dry }\end{array}$ & $\begin{array}{l}0.27 \\
0.33\end{array}$ & $\begin{array}{c}\text { Duan and } \\
\text { Bastiaanssen (2013) }\end{array}$ & $\begin{array}{l}\text { Iran Caspian } \\
\text { Sea Region }\end{array}$ & Arid Climate \\
\hline & $\begin{array}{l}\text { Correlation } \\
\text { coefficient }\end{array}$ & Monthly & 0.86 & Guo and Liu (2016) & $\begin{array}{l}\text { Lake Poyang } \\
\text { in China }\end{array}$ & Mountainous region \\
\hline & RMSE & Monthly & $44.05 \mathrm{~mm}$ & Guo and Liu (2016) & $\begin{array}{c}\text { Lake Poyang } \\
\text { in China }\end{array}$ & Mountainous region \\
\hline & NRMSE & Monthly & $31.43 \%$ & Guo and Liu (2016) & $\begin{array}{l}\text { Lake Poyang } \\
\text { in China }\end{array}$ & Mountainous region \\
\hline & BIAS & Monthly & $5.36 \%$ & Guo and Liu (2016) & $\begin{array}{l}\text { Lake Poyang } \\
\text { in China }\end{array}$ & Mountainous region \\
\hline & ME & Monthly & $7.52 \mathrm{~mm}$ & Guo and Liu (2016) & $\begin{array}{l}\text { Lake Poyang } \\
\text { in China }\end{array}$ & Mountainous region \\
\hline & $\begin{array}{l}\text { Correlation } \\
\text { coefficient }\end{array}$ & Monthly & $0.53-0.96$ & Almazroui (2011) & Saudi Arabia & Arid Climate \\
\hline
\end{tabular}

\section{CONCLUSIONS}

We validated the precipitation estimates of the TRMM3B42 V7 and TRMM3B43 V7 products by comparing them with the data from a rainfall gauge. The TRMM 3B42 V7 product performed poorly in the detection of days with and without rainfall. The reason for poor performance may be related to the inability of meteorological satellite sensors with up to 24 hours accuracy to estimate the amount precipitated, or due to the cushioning of the spatial variable over the range of individual rain gauges to create an average spatial value over an extensive area. 
However, several authors claim that individual characterization improves the application potential of such precipitation estimates, since identifying and quantifying errors allows scientists to increase the algorithms' reliability through the development of correction procedures.

We also observed that the satellite products underestimate precipitation during periods of higher rainfall and overestimate precipitation in periods of lower rainfall. This was confirmed by the categorical indices, where the number of days when the occurrence and non occurrence of precipitation were correctly identified during periods of higher rainfall. The magnitude of these errors was reduced and the agreement between the TRMM estimates and rainfall measurements was increased by increasing the data accumulation period, from daily scale to monthly. This was anticipated in view of the greater spatial and temporal variability in daily precipitation and the associated difficulty of the products to accurately model this.

\section{ACKNOWLEDGMENTS}

Partial support was provided by the 'Conselho Nacional de Desenvolvimento Científico e Tecnológico (CNPq)' and Post Graduate Program in Environmental Physics, Federal University of Mato Grosso.

\section{REFERENCES}

ADEYEWA, Z. D.; NAKAMURA, K. Validation of TRMM radar rainfall data over major climatic regions in Africa. Journal of Applied Meteorology, 42(2):331-347, 2003. https://doi.org/10.1175/15200450(2003)042<0331:VOTRRD>2.0.CO;2

ALMAZROUI, M. Calibration of TRMM rainfall climatology over Saudi Arabia during 1998-2009. Atmospheric Research, 99: 400-414, 2011. https:// doi.org/10.1016/j.atmosres.2010.11.006

ARRAUT, J. M. et al. Aerial rivers and lakes: looking at large-scale moisture transport and its relation to Amazonia and to subtropical rainfall in South America. Journal Climate, 25(2):543-556, 2012. https://doi.org/10.1175/2011JCLI4189.1
COLLISCHONN, B. et al. Performance of TRMM satellite precipitation estimates over the Upper Paraguay River Basin. Revista Brasileira de Cartografia, 59(1):93-99, 2007.

COLLISCHONN, B.; COLLISCHONN, W.; TUCCI, C. E. M. Daily hydrological modeling in the Amazon basin using TRMM rainfall estimates. Journal of Hydrology, 360(1):207-216, 2008. https://doi. org/10.1016/j.jhydrol.2008.07.032

CONDOM, T; RAU, P; ESPINOZA, JC. Correction of TRMM 3B43 monthly Precipitation data over the mountainous of Peru during the period 1998-2007. Hydrological Processes, 25:1924-1933, 2011. https:/ / doi.org/10.1002/hyp.7949

CORREA, S. W. et al. Multi-decadal Hydrological Retrospective: Case study of Amazon floods and droughts. Journal of Hydrology, 549:667-684, 2017. https://doi.org/10.1016/j.jhydrol.2017.04.019

CORREIA, F. W. S. et al. Balanço de umidade na Amazônia e sua sensibilidade às mudanças na cobertura vegetal. Ciência e Cultura, 59(3):39-43, 2007.

COSTA, M. H. et al. Atmospheric versus vegetation controls of Amazonian tropical rain forest evapotranspiration: Are the wet and seasonally dry rain forests any different? Journal of Geophysical Research, 115:1-9, 2010. https://doi. org/10.1029/2009JG001179

CULF, A. D. et al. The Albedo of Amazonian Forest and Ranch Land. In: GASH, J. H. C. et al. Radiation, temperature and humidity over forest and pasture in Amazonia. (Eds). Amazonian Deforestation and Climate, John Wiley \& Sons, Chichester, England, 175-191, 1996.

DARAND, M.; AMANOLLAHI, J.; ZANDKARIMI, S. Evaluation of the performance of TRMM Multi-satellite Precipitation Analysis (TMPA) estimation over Iran. Atmospheric Research, 190:121-127, 2017. https://doi.org/10.1016/j. atmosres.2017.02.011

DUAN, B; BASTIAANSSEN, W. G. M. First results from Version 7 TRMM 3B43 precipitation product in combination with a new downscalingcalibration procedure. Remote Sensing of Environment, 131:1-13, 2013. https://doi. org/10.1016/j.rse.2012.12.002 
FRANÇA, R. R. Climatologia das chuvas em Rondônia - período 1981-2011. Revista Geografias, 11(1), 2015.

FU, Y; LIU, G. Possible misidentification of rain type by TRMM PR over Tibetan Plateau. Journal of Applied Meteorology Climatology, 46(5): 667-672, 2007. https://doi.org/10.1175/JAM2484.1

GUO, R.; LIU, Y. Evaluation of satellite precipitation products with rain gauge data at different scales: Implications for hydrological applications. Water, 8(281):1-20, 2016. https://doi.org/10.3390/w8070281.

HODNETT, M. G. et al. Comparisons of long-term soil water storage behaviour under pasture and forest in three areas of Amazonia. In: GASH, J. H. C. et al. Radiation, temperature and humidity over forest and pasture in Amazonia. (Eds). Amazonian Deforestation and Climate, John Wiley \& Sons, Chichester, England, 57-77, 1996.

HOORNA, C. et al. The Amazon at sea: Onset and stages of the Amazon River from a marine record, with special reference to Neogene plant turnover in the drainage basin. Global and Planetary Change, 153:51-65, 2017. https://doi.org/10.1016/j. gloplacha.2017.02.005

HUFFMAN, G. J. et al. The TRMM Multi-satellite precipitation analysis (TMPA). In: Gebremichael M.; Hossain F. (eds). Satellite Rainfall Applications for Surface Hydrology. Springer, Dordrecht, 2010. https://doi.org/10.1007/978-90-481-2915-7_1

HUFFMAN, G. J. et al. The TRMM Multisatellite Precipitation Analysis (TMPA): quasi-global, multiyear, combined-sensor precipitation estimative at fine scales. Journal of Hydrometeorology, 8:38-55, 2007. https://doi.org/10.1175/JHM560.1

HUFFMAN, G. et al. Global precipitation estimates based on a technique for combining satellite-based estimates, rain gauge analysis, and NWP model precipitation information. Journal of Climate, 8(5):1284-1295, 1995. https://doi.org/10.1175/15200442(1995)008<1284:GPEBOA>2.0.CO;2

HUFFMAN, G. J.; BOLVIN, D. T. TRMM and Other Data Precipitation Data Set Documentation, NASA Global Change Master Directory Doc. Mesoscale Atmospheric Processes Laboratory, 44, 2015. http:/ / pmm.nasa.gov/sites/default/files/document_ files/3B42_3B43_doc_V7.pdf.]
HUNINK, J. E.; IMMERZEEL, W.W.; DROOGERS, P.A. High-resolution Precipitation 2-step mapping Procedure (HiP2P): Development and application to a tropical mountainous area. Remote Sensing of Environment, 140, 179-188, 2014. https://doi. org/10.1016/j.rse.2013.08.036

IMMERZEEL, W. W.; RUTTEN, M. M.; DROOGERS, P. Spatial downscaling of TRMM precipitation using vegetative response on the Iberian Peninsula. Remote Sensing of Environment, 113(2):362-370, 2009. https://doi.org/10.1016/j.rse.2008.10.004

ISLAM, M. D. N.; UYEDA, H. Use of TRMM in determining the climatic characteristics of rainfall over Bangladesh. Remote Sensing Environment, 108:164-276, 2007. https://doi.org/10.1016/j. rse.2006.11.011

ISLAM, T. et al. Stratiform convective rain delineation for TRMM microwave imager. Journal of Atmospheric and Solar-Terrestrial Physics, 133:2535, 2015. https:// doi.org/10.1016/j.jastp.2015.07.009

KIDD, C. et al. Skofronick-Jackson, G., Kirschbaum, D.B. So, How much of the Earth's surface is covered by rain gauges? Bulletin of the American Meteorological Society, 98:69-78, 2017. https://doi. org/10.1175/BAMS-D-14-00283.1

KIM, K., PARK, J.; BAIK, J.; CHOI, M. Evaluation of topographical and seasonal feature using GPM IMERG and TRMM 3B42 over FAR-East Asia. Atmospheric Research, 187:95-105, 2017. https:// doi.org/10.1016/j.atmosres.2016.12.007

KOO, M. S.; HONG, S. Y.; KIM, J. An evaluation of the tropical rainfall measuring mission (TRMM) multi-satellite precipitation analysis (TMPA) data over South Korea. Asia- Pacific Journal Atmospheric Sciences, 45(3):265-282, 2009.

NASTOS, P. T.; KAPSOMENAKIS, J.; PHILANDRAS, K. M. Evaluation of the TRMM 3B43 gridded precipitation estimates over Greece. Atmospheric Research, 169:497-514, 2016. https://doi. org/10.1016/j.atmosres.2015.08.008

QI, Y. et al. Correction of radar QPE errors for nonuniform VPRs in mesoscale convective systems using TRMM observations. Journal of Hydrometeorology, 14(5):1672-1682, 2013. https:// doi.org/10.1175/JHM-D-12-0165.1 
ROTTENBERGER, S. et al. Exchange of short-chain aldehydes between Amazonian vegetation and the atmosphere at a remote forest site in Brazil. Ecological Applications, 14(4):247-262, 2004. http://dx.doi. org/10.1890/01-6027

SOARES, A. S. D.; PAZ, A. R.; PICCILLI, D. G. A. Assessment of rainfall estimates of TRMM satellite on Paraiba state. Revista Brasileira de Recursos Hídricos, 21(2):288-299, 2016. http://dx.doi. org/10.21168/rbrh.v21n2.p288-299

TAPIADOR, F. J. et al. Global precipitation measurements for validating climate models. Atmospheric Research, 197: 1-20, 2017. http:// dx.doi.org/10.1016/j.atmosres.2017.06.021

TIAN, Y.; PETERS-LIDARD, C. D. A global map of uncertainties in satellite-based precipitation measurements. A Geophysical Research Letters, 37:L24407, 2010. http://dx.doi. org/10.1029/2010GL046008

TRENBERTH, K. E.; ZHANG, Y.; GEHNE, M. Intermittency in Precipitation: Duration, Frequency, Intensity, and Amounts Using Hourly Data. Journal of Hydrometeorology, 18:1393-1412, 2017. https:// doi.org/10.1175/JHM-D-16-0263.1

VAN DER ENT, R. J. et al. Origin and fate of atmospheric moisture over continents. Water Resources Research, 46:W09525, 2010. https://doi. org/10.1029/2010WR009127.

WANDERS, N.; PAN, M. Correction of real-time satellite precipitation with multi-sensor satellite observations of land surface variables. Remote Sensing of Environment, 160:206-221, 2015. https:/ / doi.org/10.1016/j.rse.2015.01.016.

ZHENG, X.; ZHU, J. A methodological approach for spatial downscaling of TRMM precipitation data in North China. International Journal of Remote Sensing, 36(1):144-169, 2014. https://doi.org/10.108 0/01431161.2014.995275

WILKS, D. S. Statistical Methods in the Atmospheric Sciences. International Geophysics Series, 2d ed, 91, 2006. Academic Press. 